\title{
Study of Life Education for College Freshmen in China
}

\author{
Jianfeng Zhang ${ }^{1} \&$ Xuefei $\mathrm{Li}^{2}$ \\ ${ }^{1}$ College of Humanities and Foreign Languages, Xi' an University of Science and Technology, China \\ ${ }^{2}$ Psychological Counseling Center, Chang'an University, China \\ Correspondence: Jianfeng Zhang, College of Humanities and Foreign Languages, Xi'an University of Science \\ and Technology, Lintong District, Xi'an, Shaanxi Province, 710600 China. Tel: 86-180-6697-7127. E-mail: \\ zhangjianfeng091024@126.com
}

Received: July 4, 2016

doi:10.5539/ies.v9n12p75
Accepted: August 8, $2016 \quad$ Online Published: November 24, 2016

URL: http://dx.doi.org/10.5539/ies.v9n12p75

The research is financed by Important Theory and Realistic Problem Research Program of Shaanxi Provincial Social Sciences Union (2016C033) and by Instructional Research Project of Xi'an University of Science and Technology (JG16070).

\begin{abstract}
Based on student-centred teaching strategy, the complete higher education should include the knowledge acquisition and the comprehensive development of college students. Life education is able to help college freshmen to establish an attitude towards respecting life, to cultivate lofty ideals and to stimulate learning motivation. In China, to assist freshmen in adapting campus life as soon as possible, the work of freshmen education is widespread in most universities. Base on the results of "Chinese college students' life attitudes", the convergence between life education and freshmen education is analyzed and it is feasible to carry out life education for college freshmen; meanwhile, the approaches of life education are explored and the curriculum system is established; therefore, the education perspective can be broadened and the content of freshmen education will be beneficially supplemented.
\end{abstract}

Keywords: life education, freshmen education, college freshmen

\section{Introduction}

The first year in university is the beginning of the whole campus life and it is also the crucial time, which has laid solid foundation for higher education. In China, unfortunately, because of confusion and maladjustment in the first year, many college freshmen fail in their examinations and have to stay down; moreover, some of those cannot adapt to the pace of life in universities so that anxiety and depression occur and students who are in poor psychological bearing ability even commit suicides to end the painful and insufferable college life. Therefore, in order to help them to suit campus life and learning as soon as possible, a lot of Chinese universities have launched various freshmen education, including major education, learning instruction, psychological adaption education, and so on, which is usually scheduled the first semester after their enrolment.

Based on student-centred teaching strategy, the complete higher education should include the knowledge acquisition and the comprehensive development of college students. Moreover, many grievous things have rendered us aware of the importance of life education. Life is the precondition of all teaching activities and methods, so when college students enter the gate of university, it is necessary and essential to mix the content of life education with the freshmen education. What's more, the education perspective can be broadened and the content of freshmen education will be beneficially supplemented.

\section{Literature Review}

\subsection{Life Education}

American scholar Walter (1998) proposes the concept of "life education" and he stresses the spiritual values and helping children to grow toward full maturity learning not only facts, but also innovative principles for better living. But the primary form of life education is death education which occurs in America. Yalom (2009) points out that death, to some extent, is just like shining sun and usually one is unable to stare it. Subjects "become panic at the mention of death" because it always terrorizes to people and it usually brings anxiety. Educators in 
western countries want to help people to establish systematic and scientific philosophy about life and death and to pursue sense and value of life via death education (Stewart, 2000). With the continuous development, life education is introduced into Australia and Great Britain. At the same time, the ideology of life education is rooted in curriculum and instruction design.

In China, Taiwan region is the first to incorporate life education into open curriculum (Huang, 2011). Meanwhile, the content of life education has been extensively discussed. Sun (2000) suggests that life education should include 3 levels: doctrinal philosophy of life, basic ethics and emotional education. Chang (2001) proposes that the course of life education should be divided into 5 stages: the self, others, natural environment, society and the universe so that one can embody the meaning and value of life. Huang (2011) classifies 5 major orientations of life education: religious orientation, physical health orientation, career orientation, educational orientation and thanatological orientation. He utilizes questionnaires and group interviews to set the core concepts, curriculum objectives and capacity indicators of life education.

Since 1990s, all-round quality education has been implemented in Chinese mainland. Based on taking people as a dominant factor, life education has germinated in the soil of higher education. Lai (2004) analyzes the connotation of life education from the 3 perspectives: the practice of life education, tools of life education and the fact of contempt for life. Miao (2010) indicates that life education should include physical cognitive level, mental practical level and ethical emotional level. Zhou (2010) divides life education into life-conscious education, life-value education and social-responsibility education.

In recent years, suicidal and homicidal vicious incidents happen frequently on campus in China, which urges educators to study and explore the life education for college students. In 2010, the Ministry of Education issued China's Educational Reform and Development (2010-2020), which clearly pointed out the importance of life education in all universities. It is the first time that the content of life education was mentioned in the educational reform document of national level. Therefore, life education for college students is a strategic decision of the nation and has profound historic significance.

\subsection{Life Attitude of Chinese College Students}

According to the statistics of Chinese Centre for Disease Control and Prevention in 2015, suicide rate in China is $22.23 / 100,000$ and 250,000 people commit suicide every year. What's more, suicide has become the first leading cause of death among 15-to 34-year-olds since 2010. The suicide rate of Chinese College students is about 20/100,000.

This study used "Life Attitude Scale" (LAS) authorized by Man-Ying Hsieh on 924 college students from 8 different universities to assess life attitude of undergraduates. The results are shown in Table 1.

Table 1. Comparisons life attitude with norm $(\mathrm{N}=924)$

\begin{tabular}{lcc}
\hline & $\boldsymbol{M} \pm \boldsymbol{S D}$ & Percentage \\
\hline The level of existence & $56.55 \pm 9.12$ & 88 \\
The level of independent life & $60.12 \pm 9.03$ & 69 \\
The level of ideal & $56.03 \pm 10.38$ & 79 \\
The level of life experience & $61.00 \pm 8.32$ & 91 \\
The level of love & $72.54 \pm 9.34$ & 91 \\
The level of death attitude & $58.15 \pm 9.42$ & 83 \\
Total Score & $364.39 \pm 41.26$ & 89 \\
\hline
\end{tabular}

The results indicate that although the total score of scale is higher than norm (85\%), yet the level of independent life, the level of ideal and the level of death attitude are $69 \%, 79 \%$ and $83 \%$ respectively, which are lower than $85 \%$. In other words, the general state of life attitude among Chinese college students is fairly good, but ideal of life, meaning of life, independence of life, responsibility of life and death attitude should be improved via well-directed education.

\section{The Analysis of College Students' Life Attitude}

According to the data mentioned in Table 1, generally speaking, the situation of life attitude is mainly in good 
condition, but in several levels, some problems, which are easy to trigger psychological crisis and to induce vicious incidents so that have an impact on qualities of life and the future development of life, still exist. Various reasons are responsible for the phenomena mention above.

\subsection{Exam-Oriented Education}

The value of life has been neglected by students because of long-term examination-oriented education in China. Due to the unbalanced distribution of public education resources, academic competitions are increasingly severe and students have many pressures upon their schoolwork. Although quality education has been implemented for many years, exam-oriented education is given priority in the basic stage education. The key point of instruction still focuses on cultivation of knowledge acquisition and the grade in exam is the only index for academic evaluation. The single pattern of instructional practice and the simplistic index could facilitate instructors or parents to ignore ideological trends and psychological qualities of students; moreover, the meditation on the meaning and value of life is limited as well. Therefore, when these students attend universities and confront lax learning environment on campus, many freshmen have hardly had time to adapt the new atmosphere so that they lack ideal of life and learning subjective without purpose and killing time.

\subsection{Circumscribed Life}

Circumscribed life and simple life content pose lack of necessary abilities to deal with life for many freshmen. Owing to academic pressure in high school, students' time and energy are usually used in learning, so the life content is rather simple and the relationships are always confined in school and family. They are short of practice and train for life activities. After the college entrance examination, the ever superiority of freshmen vanishes; simultaneously, they find that the reality of university is totally different from the ideal and the accustomed life style is gradually displaced by the new patterns of learning and connection. Therefore, during the shifted progress, if the coping modes are inappropriate, some negative emotion, such as anxiety, depression, will occur and dispose cause negative life attitude.

\subsection{Living Environment}

Because of the policy of Family Planning in China, the populations of only child are of a large proportion in college students. Thanks to the special living environment of only child, they have specific physiological features, such as dependence, self-confidence but inferiority. Because of parents' over protection, the only child on campus lacks independence in life, thought and action; moreover, they have few abilities to organize and adjust their development of life and cannot be the master of their own life. Meanwhile, those college freshmen are short of responsibilities. When in trouble, they are unable to face difficulties independently, so their emotion is fragile and frustrated easily.

\section{The Necessity and Feasibility of Life Education for College Freshmen}

It is necessary and significant to launch life education for college freshmen, which can assist them in cultivating lofty ideals, thinking meaning and value of life deeply and stimulating learners' autonomy. In addition, life education can prevent suicide and other vicious incidents effectively; moreover, based on freshmen education in universities, life education is feasible no matter in time or in the targets and content of education.

\subsection{Puberty and Critical Time}

College freshmen hit puberty and it is the critical time to establish the world view and life view. According to the personality development theory (Erikson, 1994), freshmen are in the stage of self-identity, which they will question themselves "who am I? How do I fit in? Where am I going in life?" Erikson believes that if the students are allowed to explore, they will conclude their own identity. If, however, parents and teachers continually push him/her to conform to their views, the students will face identity confusion. Therefore, if freshmen are short of appropriate guidance, it is hard to form comprehensive self-identity and positive life view so that the learning and development of their own will be affected negatively. The survey finds that a number of freshmen do not have right cognition in the value of life and the independent life is not accurate; furthermore, some of them hold the negative attitudes toward the life existence. The data are shown in Table 2. So it is necessary to launch life education at the beginning of the higher education and to instruct or guide them positively. 
Table 2. The results of life attitude for freshmen $(\mathrm{N}=924)$

\begin{tabular}{ll}
\hline Excerpts from the questionnaire & Agreement (\%) \\
\hline I think it is OK to live for myself. & 84.3 \\
There is nothing that I want to accomplish. & 64.9 \\
I don't feel that I can control the direction of my life. & 42.0 \\
I believe that when in trouble, one should accept the destiny. & 76.4 \\
I have thought of suicide or death more than once when in trouble. & 34.1 \\
I am motivated by desperation sometimes. & 26.3 \\
\hline
\end{tabular}

\subsection{The Seasonable Time}

The first year on campus is the seasonable time for life education. Prevention suicide has become a world-concerned topic. In order to provide worldwide commitment and action to prevent suicides, the International Association for Suicide Prevention collaborates with the World Health Organization to host World Suicide Prevention Day that is an awareness day observed on September $10^{\text {th }}$ every year. In China, most freshmen enter colleges and universities in September as well. Therefore, life education can be given during the orientation program for new students at the beginning of higher education so that freshmen education can be enriched and based on Suicide Prevention Day, students can be inspired to cherish life. Meanwhile, after the fierce College Entrance Examination, the body and mind of college freshmen are in placid and quiet time. Their intelligence has reached a golden stage which is appropriate to deep and dispassionate consideration. Life education enables them to explore the meaning of life and to pursue the direction of self-development.

\subsection{Life Education and Freshmen Education}

In the narrow sense, the purpose of life education is of prevention suicide, but the comprehensive life education should instruct students to cherish life, to love life, to respect life, and to cultivate their optimistic life attitudes so that they can form the right life view to reflect the meaning of life actively. On the other hand, the content of freshmen education in most Chinese universities mainly focuses on the adaption of campus life for new students, so the basic purpose is to instruct freshmen how to own the meaningful and colourful campus life. From this perspective, the ultimate goal of life education and freshmen education is overlapped and both of them hope that students can acquire full development on campus via effective education. Additionally, because of the basic and strategic position of freshmen education, it has been adopted in the talents training scheme. Life education is the beneficial supplement of freshmen education and can embody human desires as the main focus on higher education. Therefore, the convergence between life education and freshmen education renders feasible in Chinese colleges and universities.

\section{Approaches of Life Education for College Freshmen}

The harsh reality has alarmed for life education on campus. Although the freshmen education in Chinese universities has laid macro and grand realistic basis for life education, yet some new approaches need to be explored to further deepen on the basis of the educational pattern because of the particularity of life education.

\subsection{Psychological Health Education}

The life education can be brought into psychological health education and has become one of the key constitutional ingredients in the whole higher education. When freshmen enter colleges, they will confront many new changes, such as new life style, new living environment, new learning mode and new relationship. All of these new changes will be prone to anxiety, tension, depression and other negative emotions. So based on psychological health education, life education mainly helps freshmen to adjust their emotions and to adapt the campus life as soon as possible. Furthermore, life education can utilize some ways of psychology to aid freshmen in acquiring cognitive abilities, cultivating positive qualities and life attitudes. Establishing pleasure and enriched emotional base will effectively reduce the occurrence of crisis events. Besides, in the first year of the college, group counselling with the theme of life can be held to target the only child, minority students or poverty students respectively. During the activities, the similar background identities are easier to communicate and to get more social support so that freshmen are able to find the sense of belonging on campus.

\subsection{Peer Assistance}

Peer assistance among freshmen can be utilized in life education. The meaning of life cannot independent on 
lofty belief and ideals. Some students get confused in belief and word view; meanwhile, peer identity is an important feature in college students' interpersonal relations. They like to contact with their classmates or roommates and they are apt to admire or identify their peers. Therefore, students' union and club activities are useful platforms for freshmen to adapt campus life and to form right world view. In life education, peer assistance and contacts should be fully adopted to offer the mode of mock or identity for freshmen.

\subsection{Curriculum System of Life Education}

In America, the curriculums of life education have been adopted in the credits system of higher education since 1990s, and students own fully independent right to choose those curriculums to get credits; moreover, many famous professors will instruct or guide in seminars about love, life and death. Unfortunately, most Chinese universities have not set up these curriculums so far. Therefore, Chinese higher education should refer to the practice of American universities and establish curriculum system of life education. In classroom instruction, the origins of life can be explained systematically, and students can be taught how to face death, how to evaluate life value and how to distinguish the happy life and the meaningful life. Freshmen will cherish their lives and consider their responsibilities and the value of life rationally via curriculums of life education and teachers' instruction.

Based on the information technology, curriculum system of life education can be divided into 3 stages: fundamental curriculums which emphasis on safety education and meet the needs of basic security; expanding curriculums which pay attention to the development of cultural taste and quality of life; upgrading curriculums which stress to mold students' life view and life value. Therefore, fundamental curriculums should include the content of physical hygiene, crisis management and safety education; expanding curriculums introduce laws \& rules, physiological health and positive physiology; upgrading curriculums mainly focus on life philosophy and career planning. Figure 1 shows the details.

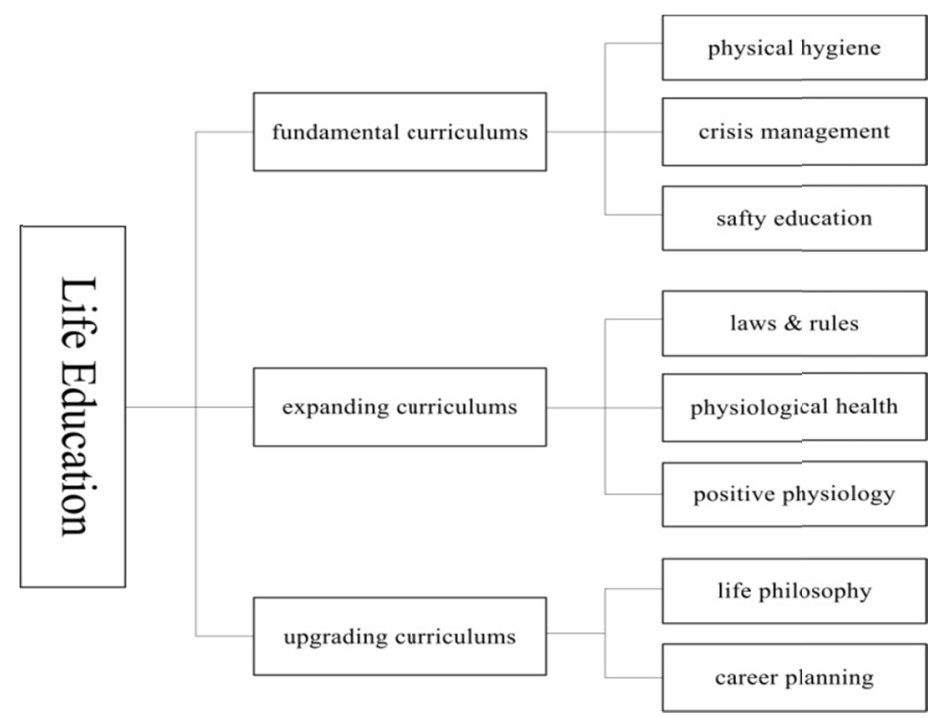

Figure 1. Curriculums system of life education

\section{Conclusion}

The essence of higher education is a kind of social educational activity that is mainly concerned in cultivating people, shaping people, developing people and improving people. So life education for college freshmen should concern about life and call for human being as well as love for all creatures. Life education is not moralization in theoretical level but the sense and experience of living reality. On campus, freshmen can be organized to discuss about gambling, addiction and suicides etc. These living examples will warn them to cherish the everyday of life and to form positive attitudes towards learning and work.

The improvement of higher education and college students is the basic guarantee of the strategies of developing the country through science and education, which is closely related to the development of China. Life education is a huge systematic project and a tough task that should be embodied in every link of higher education. "Well begun is half done." So when freshmen enter colleges and universities, life education can help them to create 
favourable condition for their whole campus life. Teaching resources should be fully utilized to enrich the approaches and forms of life education for college freshmen.

\section{References}

Chang, L. C. (2001). The first national conference of general affective teaching. Da-Yeh University, Yuanlin.

Chinese Centre for Disease Control and Prevention. (2015). The cause of death statistical findings in China. Retrieved from http://www.chinacdc.cn/tjsj_6693/gjwstjsh_6796/

Erikson, E. H. (1994). Childhood and Society. W. W. Norton \& Company.

Huang, Y., Wang, P., \& Lin, C. (2011). Developing the curriculum and instruction model for suicide prevention and life education in Taiwan. Asian Perspectives and Evidence on Health Promotion and Education, 10, 13-20. http://dx.doi.org/10.1007/978-4-431-53889-9_2

Lai, X. (2004). An analysis of life education in college students. Journal of Chuangchun University of $\begin{array}{lllll}\text { Technology (Higher Education Study } & \text { Edition), } & \text { 25(1), }\end{array}$ http://dx.doi.org/10.3969/j.issn.1674-1382.2004.01.012

Miao, T. (2010). Study of life education in new period. Journal of Jilin TV \& Radio University, 4, 37-38.

Stewart, A. E., Lord, J. H., \& Mercer, D. L. (2001). Death notification education: A needs assessment study. Journal of Traumatic Stress, 14(1), 221-227. http://dx.doi.org/10.1023/a:1007808220228

Sun, H. C. (2000). The foundation of the meaning and the philosophy of life education. Paper presented at the life education and educational innovation conference, Fu Jen Catholic University, Taipei.

Walter, J. D. (1998). Education for life: Preparing Children to Meet the Challenges. Crystal Clarity Publishers.

Yalom, I. D. (2009). Staring at the Sun, Overcoming the Terror of Death. China Light Industry Press.

Zhou, Y. (2010). Enhancing life education and promoting mental health in college students. Modern Education Science, 6, 142-144. http://dx.doi.org/10.13980/j.cnki.xdjykx.gjyj.2010.11.030

\section{Copyrights}

Copyright for this article is retained by the author(s), with first publication rights granted to the journal.

This is an open-access article distributed under the terms and conditions of the Creative Commons Attribution license (http://creativecommons.org/licenses/by/4.0/). 